\title{
透析患者の滑液包炎の臨床病理学的検討 一滑液包の滑膜アミロイド沈着症一
}

$\begin{array}{lllllll}\text { 平 野 宏 } & \text { 加藤 } & \text { 博 孝 } & \text { 丹田 信也 } & \text { 徐 義 之 } \\ \text { 野 村 信 介 } & \text { 栄 本 } & \text { 忠俊 } & \text { 松谷 } & \text { 拓 郎 } & \text { 大沢 } & \text { 源 吾 } \\ \text { 川崎医科大学腎臟内科 } & & & & & \end{array}$

key words：滑液包炎，滑膜炎， $\beta_{2}$-microglobulin, 透析アミロイドーシス，骨囊腫

〈要旨〉

長期血液透析患者に合併した, 滑液包炎 15 例の臨床病理学的検討を行った。男性 8 例, 女性 7 例. 平均年齢 $54 \pm 7$ 歲。平均透析歴 $12 \pm 3$ 年. 滑液包炎の罹患部位は, 股関節部 4 例, 足関節部 3 例, 手関節部 3 例, 肘関節部 3 例, 肩 関節部 1 例, 膝関節部 1 例であった。 それれぞれの関節周囲部の腫脹 (腫瘤あるいは囊腫形成) と発赤, 疼痛を訴えた。 腫脹部の超音波, CT, MRI 所見では, 関節腔とは明らかに離れた滑液包の囊腫状拡張が証明された。発熱等の全身症 状を訴える患者はいなかった。1 11 例が手根管症候群を合併し, 手根管開放術を施行した。 4 例では罹患部近傍の骨囊 腫 (bone cyst) の所見がみられ，3例では皮下の腫瘤形成型の石灰沈着がみられた，滑液包の炎症細胞浸潤，線維性

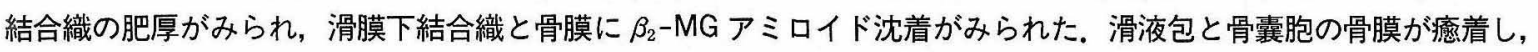
骨壞死所見を認める症例もあった。穿刺液は淡黄色, 透明, 粘稠な滑液で, カルシウム塩の結晶を認める症例もあっ た。 遊離細胞の電顕観察で, アミロイド線維が証明された。一般細菌, 真菌, 結核菌の培養はいずれも陰性であった。 長期透析患者に合併した滑液包炎は, 滑膜に $\beta_{2}-M G$ アミロイド線維の沈着を認めたことより透析アミロイド症の一 つと考えられた。この滑液包炎は, 骨囊腫や腫瘤状石灰沈着との関連性も推測された。 今後, 透析患者の訴える関節 痛の中には，滑液包资の存在も考慮しなければならないと考えられた.

\section{Clinicopathological studies of bursitis in patients on hemodialysis : Bursitis in association with synovial amyloidosis}

Hiroshi Hirano, Hirotaka Kato, Shinya Tanda, Yoshiyuki Jyo, Shinsuke Nomura, Tadatoshi Eimoto, Takuro Matutani, Gengo Osawa

Division of Nephrology, Department of Internal Medicine, Kawasaki Medical School

The clinical and pathological pictures of synovitis in 15 patients ( 8 male, 7 female) on long-term hemodialysis were studied. The average age of the patients was $54 \pm 7$ years and the average period of hemodialysis was $12 \pm$ 3 years. They developed swelling, redness, and pain in the region of the bursa around the large joints : the hip (four patients), ankle (three), hand (three), elbow (three), and shoulder (one). The dialated bursae could be distinguished by CT and MRI findings. Eleven patients had carpal tunnel syndrome, for which a carpal tunnel release operation was done, four had bone cysts, and three had tumorous calcification. The infiltration of inflammatory cells, fibrous thickening, and $\beta_{2}-M G$ amyloid fibrils were recognized in the synovial tissues. In some cases with bone cysts, both adhesions of the synovial capsule with periosteum and bone necrosis were recognized. Fluid taken from the bursae was yellow, rather than turbid synovial fluid, and showed calcium crystals in some cases. Ultrastructurally, amyloid fibrils and free synovial cells were recognized in the synovial fluid. Culture of the fluid was negative. Based on the presence of $\beta_{2}-M G$ amyloid in synovial tissues of the bursa, this bursitis in dialysis patients is considered to be a dialysis-associated amyloidosis. The results of this report suggest that dialysis

\footnotetext{
平野宏 川崎医科大学腎臓内科市 701-01 倉敷市松島 577 (0864-62-1111)
}

〔受付: 平成 4 年 4 月 14 日, 受理: 平成 4 年 9 月 30 日〕 
bursitis is related to bone cysts and tumorous calcification. We must, therefore, include bursitis as a possible diagnosis in patients complaining of arthralgia duruing long-term hemodialysis.

\section{緒言}

骨・関節障害は，長期透析患者の重要な合併症の一つ である，腎性骨異栄養症に比べると，関節障害の成因や 対策の検討は少ない.透析患者の関節障害の原因として， これまでに感染症 ${ }^{1}$, 結晶沈着 ${ }^{21}$, 石灰沈着 ${ }^{3}$ などが報告さ れている。最近，関節滑膜のアミロイド沈着に関連した 大，中関節の障害が注目されるようになり，関節滑膜や 関節包抢よび滑液中に $\beta_{2}$-microglobulin $\left(\beta_{2}-\mathrm{MG}\right)$ アミ ロイドの沈着が証明されている ${ }^{4 \sim 6)}$.

我々は, 長期透析患者で, 関節周辺の囊胞状腫瘤と疼 痛を訴える滑液包炎 15 例を経験した。これまでに透析患 者に合併した滑液包炎の報告 ${ }^{7,8)}$ は少なく，その成因や臨 床的意義については不明である.透析患者の滑液包炎は， 滑膜の $\beta_{2}-\mathrm{MG}$ アミロイド沈着と関連した病変であり, また骨囊胞 (bone cyst) や腫瘤状石灰沈着 (tumoral calcinosis）の発現にも関係していることが推測された ので報告する。

\section{対象と方法}

1990 年 4 月から 1992 年 1 月の期間に，滑液包炎を合 併した血液透析患者 15 例の臨床病理学的検討を行った。 いずれの症例も原疾患に腎アミロイド症はなく，また慢 性関節リウマチや痛風の合併もみられなかった。透析に 関連した滑液包炎の診断は，表 1 に示す基準で行った。 9 例の滑液包摘出術材料と, 6 例の滑液包滑膜の生検材 料を病理組織学的に観察した。

\section{結果}

1. 臨床所見

表 2 に 15 症例の臨床所見をまとめた。男性 8 例, 女性 7 例. 年齢は $42 \sim 64$ 歳, 平均 $54 \pm 7$ 歳. 透析歴は $9 \sim 16$ 年, 平均 $12 \pm 3$ 年. 滑液包炎の罹患部位 (図 1 ) は, 股関 節部(iliopectinea bursa) 4 例, 足関節部(subcutanea calcanea bursa) 3 例, 手関節部 (intermetacarpophalangeae bursa) 3 例, 时関節部 (subcutaneaolecrani bursa） 3 例, 肩関節部（subacromialis bursa） 1 例, 膝蓋関節部 (suprapatellaris bursa) 1例であった. 全 例で，それぞれの関節周辺部の腫脹（腫瘤あるいは囊腫 形成) と発赤, 疼痛を訴元た. 腫脹部の超音波, CT (図 2), MRI (図 2) 所見では, 滑液包の囊腫状の拡張が関 節腔とは明らかに区別されて証明された。発熱等の全身 症状を訴える症例はなかった。血液検查では, C-PTH 值 $3.6 \pm 3.4 \mathrm{ng} / \mathrm{m} l, \beta_{2}-\mathrm{MG}$ 值 $56 \pm 16 \mathrm{mg} / l$, アルミニウム $43 \pm 32 \mu \mathrm{g} / \mathrm{l}$, 鉄 $138 \pm 44 \mu \mathrm{g} / \mathrm{d} l$, フェリチン $244 \pm 258$

表 1 Criteria of dialysis-associated bursitis

1. 大および中関節の周辺部の腫脹（腫瘤あるいは需腫形成） と疼痛を訴える。

2. 局所の発赤や熱感は伴わないことが多い。

3. 穿刺液は, 無色透明な粘稠な滑液である. 滑液細胞診でア ミロイド線維を証明する。

4. 腫脹部位のエコー, CT, MRI 等で, 関節腔とは区別され る.

5. 発熱等の全身の急性炎症所見にそしい.

表 2 Summary of clinical findings

\begin{tabular}{|c|c|c|c|c|c|c|c|c|c|c|c|c|c|c|c|c|c|}
\hline 症例 & 年齢 & 性 & 原疾患 & $\begin{array}{c}\text { 透析歴 } \\
\text { 年 }\end{array}$ & $\begin{array}{l}\text { 罹患部位 } \\
\text { (滑液包) }\end{array}$ & & 骨囊腫 & $\begin{array}{l}\text { 手根管 } \\
\text { 症候群 }\end{array}$ & $\begin{array}{l}\text { 腫 瘤 型 } \\
\text { 石灰沈着 }\end{array}$ & $\begin{array}{l}\text { 滑 液 包 } \\
\text { 石灰沈着 }\end{array}$ & $\begin{array}{c}\beta_{2}-\mathrm{MG} \\
\mathrm{mg} / \mathrm{l}\end{array}$ & $\begin{array}{c}\mathrm{C}-\mathrm{PTH} \\
\mathrm{ng} / \mathrm{m} l\end{array}$ & $\begin{array}{c}\text { アルミニウム } \\
\mu \mathrm{g} / l\end{array}$ & $\begin{array}{c}\text { 鉄 } \\
\mu \mathrm{g} / \mathrm{d} l\end{array}$ & $\begin{array}{c}\text { フェリチン } \\
\mathrm{ng} / \mathrm{m} l\end{array}$ & $\begin{array}{l}\mathrm{CRP} \\
\mathrm{mg} / \mathrm{d} l\end{array}$ & $\begin{array}{l}\text { WBC } \\
/ \mathrm{mm}^{3}\end{array}$ \\
\hline 1. & 57 & 男 & 慢性腎炎 & 14 & 腸 & 恥 & $(-)$ & $(+)$ & $(-)$ & $(-)$ & 62 & 2.2 & 28 & 124 & 52 & $<0.3$ & 6,300 \\
\hline 2. & 56 & 男， & 慢性腎炎 & 10 & 腸 & 刵 & $(+)$ & $(+)$ & $(+)$ & $(t)$ & 46 & 3.1 & 12 & 152 & 250 & $<0.3$ & 5,300 \\
\hline 3. & 50 & 女 & 慢性腎炎 & 13 & 腸 & 恥 & $(+)$ & $(+)$ & $(-)$ & $(-)$ & 82 & 2.0 & 52 & 130 & 102 & 1.2 & 8,900 \\
\hline 4. & 60 & 男 & 慢性腎炎 & 9 & 腸 耳 & 恥 & $(-)$ & $(+)$ & $(-)$ & $(-)$ & 66 & 2.0 & 24 & 85 & 324 & 3.2 & 9,800 \\
\hline 5. & 42 & 女 & 慢性腎炎 & 11 & 腫骨皮 & & $(+)$ & $(+)$ & $(-)$ & $(+)$ & 68 & 12.0 & 35 & 126 & 85 & $<0.3$ & 3,200 \\
\hline 6. & 45 & 男 & 慢性腎炎 & 11 & 腫骨皮 & & $(-)$ & $(-)$ & $(t)$ & $(+)$ & 42 & 11,8 & 132 & 170 & 89 & $<0.3$ & 6,500 \\
\hline 7. & 47 & 男 & 慢性腎炎 & 10 & 腫骨皮 & & $(-)$ & $(+)$ & $(-)$ & $(-)$ & 56 & 2.0 & 78 & 88 & 102 & $<0.3$ & 5,600 \\
\hline 8. & 62 & 女 & 慢性腎炎 & 15 & 中手指節 & & $(+)$ & $(+)$ & $(-)$ & $(-)$ & 36 & 2.2 & 86 & 180 & 58 & $<0.3$ & 4,100 \\
\hline 9. & 60 & 女 & 慢性腎炎 & 12 & 中手指節同 & & $(-)$ & $(+)$ & $(+)$ & $(+)$ & 42 & 2.5 & 30 & 197 & 96 & $<0.3$ & 3,200 \\
\hline 10. & 48 & 男 & 慢性腎炎 & 16 & 中手指節同 & & $(-)$ & $(-)$ & $(-)$ & $(-)$ & 68 & 2.0 & 39 & 64 & 75 & $<0.3$ & 3,100 \\
\hline 11. & 64 & 女 & 慢性腎炎 & 10 & 肘頭 皮 $^{-}$ & & $(-)$ & $(+)$ & $(-)$ & $(-)$ & 36 & 2.0 & 21 & 152 & 120 & $<0.3$ & 3,500 \\
\hline 12. & 48 & 男 & 慢性腎炎 & 16 & 时頭皮 & 下 & $(-)$ & $(+)$ & $(-)$ & $(-)$ & 86 & 1.6 & 24 & 120 & 111 & $<0.3$ & 4,200 \\
\hline 13. & 62 & 女 & 慢性腎炎 & 16 & 肘頭 皮 & & $(-)$ & $(-)$ & $(-)$ & $(-)$ & 60 & 3.6 & 75 & 210 & 89 & 1.6 & 6,800 \\
\hline 14. & 54 & 女 & 慢性腎炎 & 12 & 肩 峰 & 下 & $(-)$ & $(t)$ & $(-)$ & $(+)$ & 42 & 1.6 & 23 & 187 & 98 & $<0.3$ & 4,600 \\
\hline 15. & 49 & 男 & 慢性腎炎 & 9 & 膝蓋骨 & 上 & $(-)$ & $(-)$ & $(-)$ & $(+)$ & 46 & 2.8 & 26 & 98 & 145 & $<0.3$ & 2,350 \\
\hline$\overline{\mathrm{X}}$ & 54 & & & 12 & & & & & & & 56 & 3.6 & 43 & 138 & 244 & & \\
\hline$\pm \mathrm{SD}$ & 7 & & & 3 & & & & & & & 16 & 3.4 & 32 & 44 & 258 & & \\
\hline
\end{tabular}



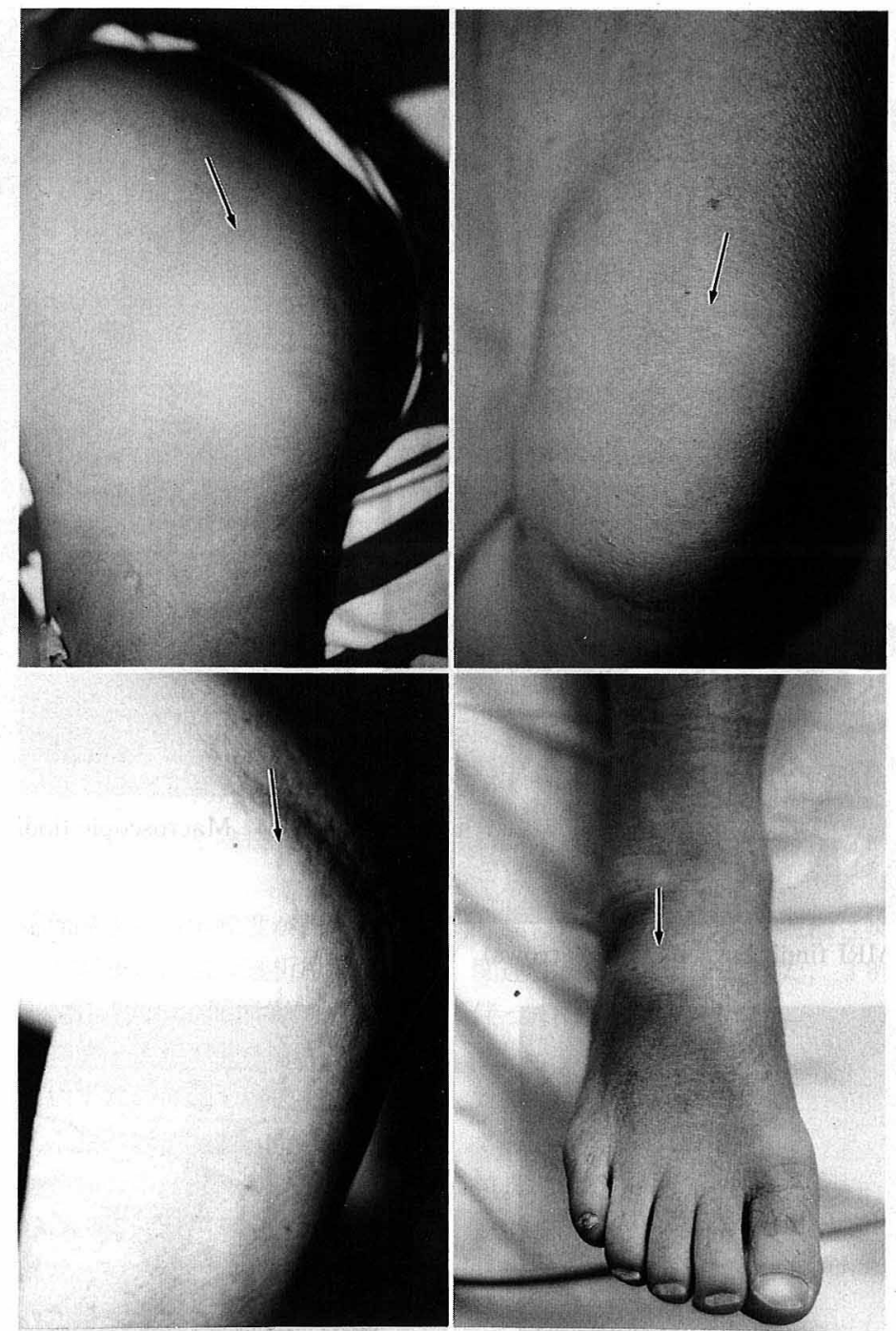

図 1 The sites of bursitis (arrows) -in proximity to hip joint (upper left), knee joint (upper right), elbow joint (lower light), ankle joint (lower right)

$\mathrm{ng} / \mathrm{m} l$. CRP 陽性は 3 例で, 末血白血球増多は 2 例でみ られた。 11 例が手根管症候群を合併し, 手根管開放術を 施行した。 4 例では罹患部近傍の骨囊胞の所見（図 3 ）， 3 例では腫瘤状石死沈着の所見，6 例では滑液包の石死 沈着の所見がみられた。

2. 滑液包炎の手術肉眼的所見

滑液包は囊腫状（図 4) に腫大し, 滑液包と近傍の関 節腔と交通を認める症例もあった. 包壁は線維性に肥厚 し, 内容物はやや粘稠度の増した滑液であった. 腫瘤状 石死沈着を合併した症例では, 滑液中に白色粒子を含ん だミルク様の液体がみられた。骨囊胞を合併した症例で
は，線維性に肥厚した包壁が骨膜と症着し，骨の壊死お よび破壊を伴っていた。

\section{3. 滑液包炎の病理組織所見}

全例で，同様な所見がみられた，滑液包の炎症細胞浸 潤, 粘液性浸出物の貯留, 線維性結合織の肥厚がみられ た.アミロイド沈着は，包壁の滑膜下結合織と骨膜にみ られ(図 5 ), 免疫組織学的には $\beta_{2}-\mathrm{MG}$ が陽性であった。 電顕学的 (図 6) には, $12 \mathrm{~nm}$ 前後のアミロイド細線維 が束状あるいは集簇性にみられた。

4. 滑液包の滑液所見

穿刺液は淡黄色，透明，粘稠な滑液であり，ミルク様 

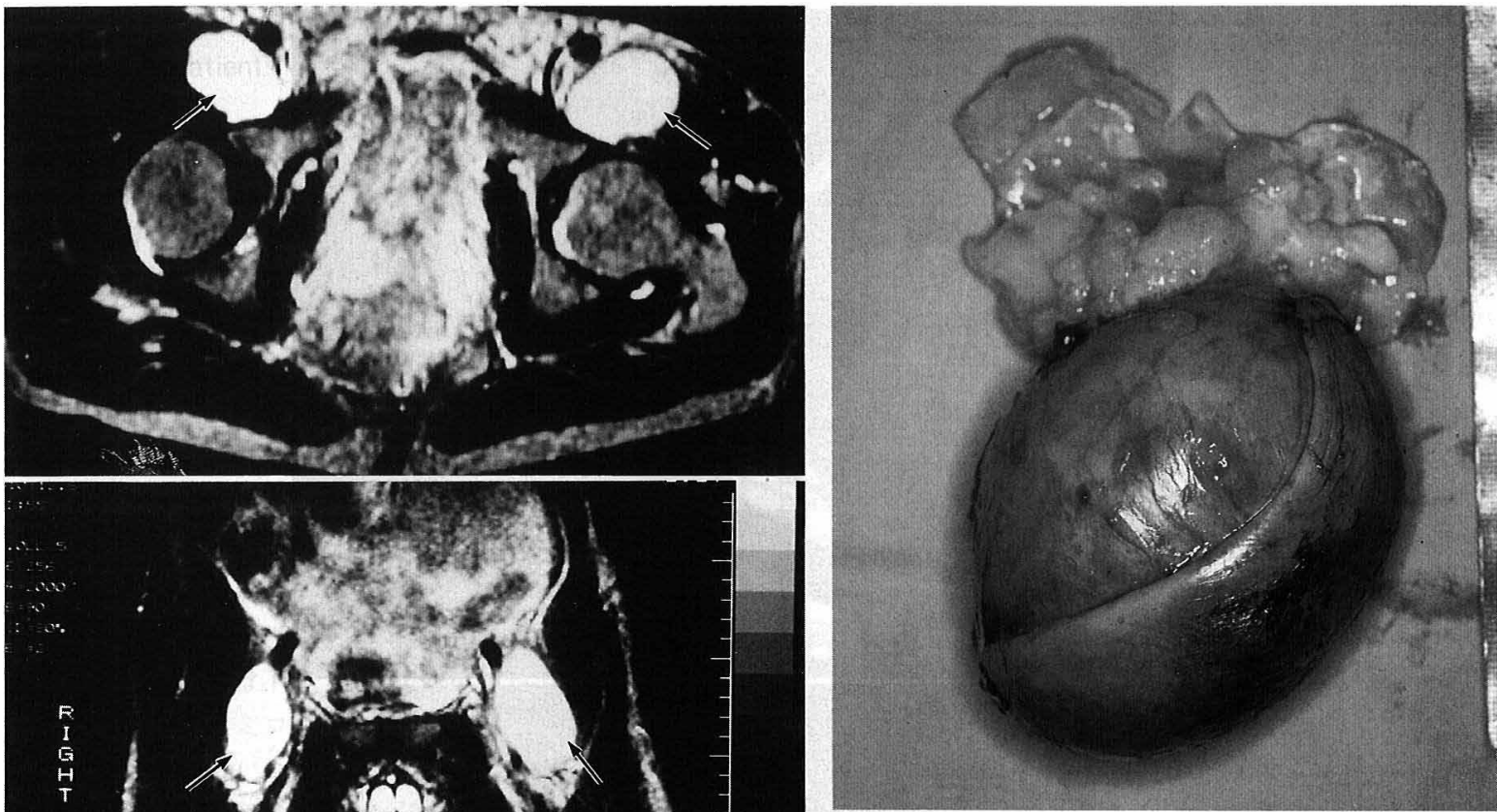

図 4 Macroscopic finding of extracted burusa

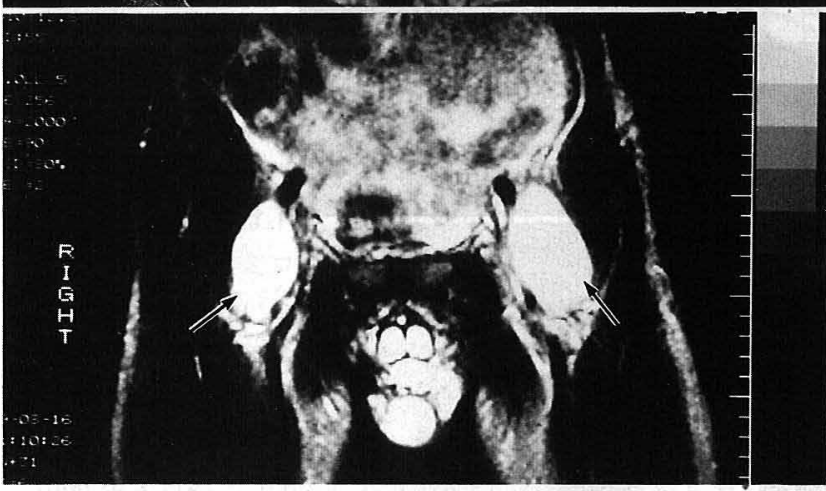

図 2 CT and MRI findings of bursitis (arrows)
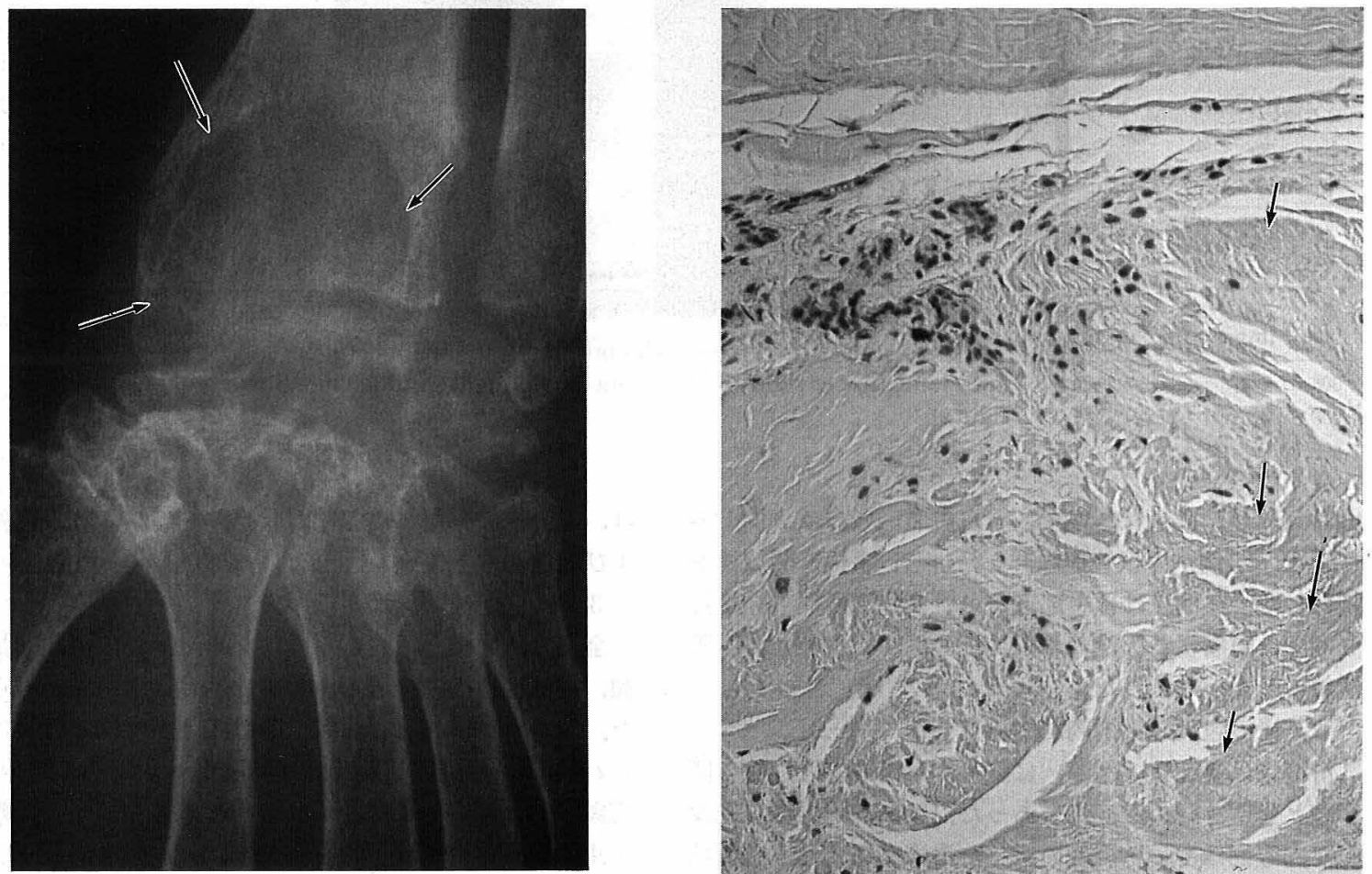

図 3 Bone cysts in proximity to bursitis (arrows)

図 5 Amyloid deposision (arrows) in the synovial tissues $(\times 400)$ 


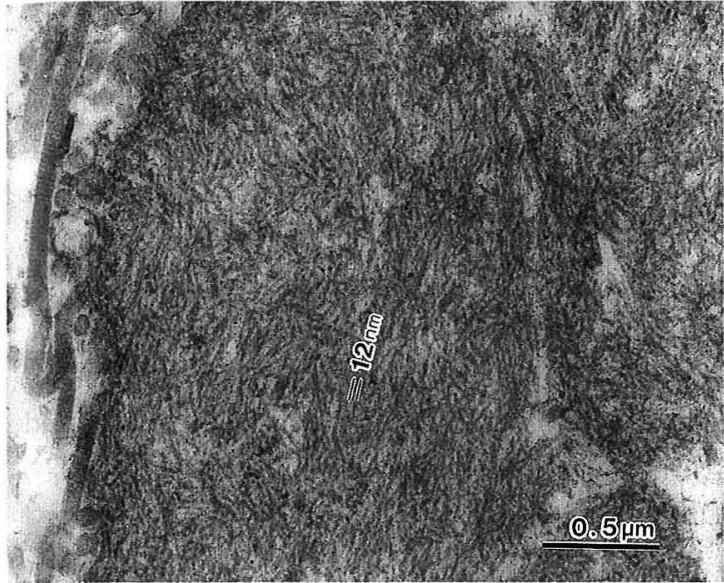

図 6 Ultastructural picture of amyloid firils

液体中には，カルシウム塩の結晶が認められた。遊離細 胞の電顕観察では, 少数の好中球と単球に混じって避離 滑膜細胞とアミロイド細線維が証明された(図 7 )。一般 細菌, 真菌, 結核菌の培養は, いずれも陰性であった。

\section{考察}

長期透析患者では骨・関節障害の合併頻度が高く, 骨 痛や関節痛に悩まされることが多い. 血液透析患者のア ンケート調查 ${ }^{9}$ では，骨痛は $31.7 \%$ に, 関節痛は $45.4 \%$ にみられた。関節痛の出現頻度と透析期間とは相関があ り, 透析導入後 6 年目では約半数の症例で関節痛がみら れた. 関節痛の好発部位は, 腰, 肩, 上肢, 下肢の順で あったが，患者の訴える関節痛の中には，関節障害とは 直接関係ないものもしばしばみられた，滑液包炎がその 一つで, 関節から少し離れた部位の腫脹, 発赤と疼痛を 訴えた。透析患者に合併した滑液包炎の報告はほとんど なく ${ }^{7,8)}$ ，その原因および臨床的意義は不明である.今回， 血液透析患者に滑液包炎を合併し，滑液包摘出術あるい は滑膜生検を施行した 15 例の臨床病理学検討を行った。

滑液包は，全身の筋肉間あるいは筋と腱および骨の間 にある。袋状の結合組織の間隙に滑液の溜ったもので, 運動の際に筋肉を保護する役割をもっている。滑液包は 滑膜に内張りされ，近傍の関節腔と交通しているものも ある，滑液包炎は，関節周囲の滑液包に疼痛，発赤，腫 脹を認めるのが特徴で, 健常人では慢性の外傷により生 じ, プロの運動選手の肩や，頻繁に膝をつく人の前膝蓋 包，下滕蓋包などによくみられる。炎症をおこしている 滑液包の壁は著しく肥厚し, 内腔壁はフィブリン性の浸 出物のため充血し，粗毛状である。その他に，慢性関節 リウマチ ${ }^{10)}$, 外傷 ${ }^{11)}$, 敗血症 ${ }^{12)}$, 結核 ${ }^{13)}$ でも滑液包炎を合 併した報告がある。

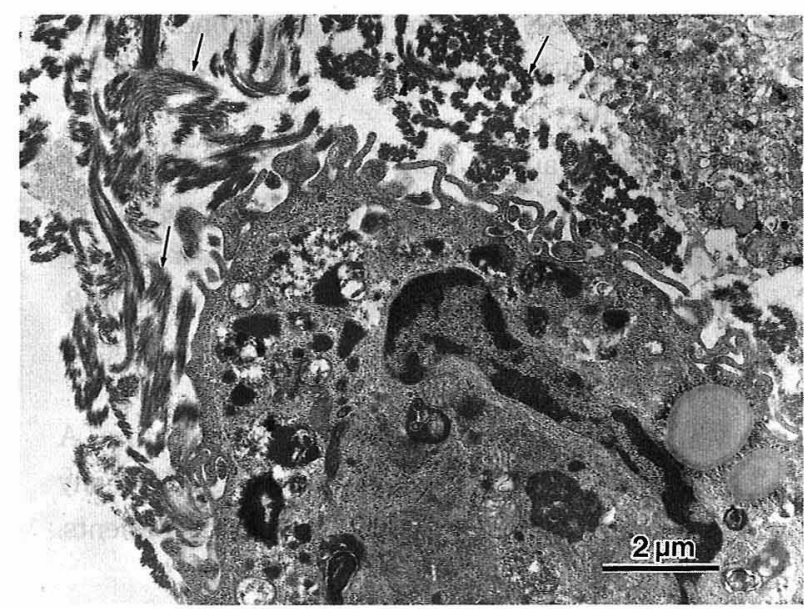

図 7 Amyloid fibrils (arrows) in the bursal fluid

透析患者に合併した滑液包炎の原因は不明であるが， 滑液包の滑膜に $\beta_{2}-\mathrm{MG}$ アミロイド線維の沈着を認めた ことより，滑液包炎も透析アミロイド症の一つと考えら れた. 4 例の滑液包炎では, 近傍の骨囊胞病変を伴って いた。これらの症例では，アミロイド沈着は滑液包から 骨膜に連続してみられ，滑液包炎と骨囊胞病変の発現に 関連性が推測された。また， 3 例では腫瘤状石灰沈着を 伴っていた，滑液中にカルシウム塩の結晶が存在してお り，腫瘤状石灰沈着の成因の一つに滑液包炎が考えられ た。最近, 腫瘤形成型アミロイド沈着症が報告 ${ }^{14 \sim 16) さ れ ~}$ ている。これらは大関節周辺部に認められて扔り，滑液 包炎抒よび滑液包のアミロイド沈着が推測されている が，我々の症例はこの推測を支持するものであった．

\section{結論}

長期血液透析患者に合併した滑液包炎は，滑膜包滑膜 に $\beta_{2}-\mathrm{MG}$ アミロイド線維の沈着を認めたことより，透 析アミロイド症の一つと考えられた。この滑液包炎は， 骨囊胞, 腫瘤状石圧沈着や腫瘤形成型アミロイド沈着症 とも関連した病態だと推測された，今後，関節痛を訴え る長期透析患者では, 滑液包炎の存在も考慮しなければ ならないと考えられた。

\section{文献}

1) Matthews M, Shen FH, Lindner A, Sherrard DJ : Septic arthritis in haemodialyzed patients. Nephron $25: 87-89,1980$

2) Hoffman GS, Schumacher HR, Paul H, Cimerian $\mathrm{V}$ : Calcium oxalate microcrystalline-associated arthritis in end-stage renal disease. Ann Intern Med $97: 36-42,1982$ 
3) Mirahmadi KS, Coburn JW, Bluestone R : Calcific periarthritis and hemodialysis. JAMA 223 : 548-549, 1973

4) Hurst NP, Van den Berg R, Disney A, Alcock M, Albertyn L, Green M, Pascoe V : 'Dialysis related arthropathy' : a survey of 85 patients receiving chronic haemodialysis with special reference to $\beta_{2}$ microglobulin related amyloidosis. Ann Rheum Dis $48: 409-420,1989$

5) Maury CPJ : $\beta_{2}$-microglobulin amyloidosis. A systemic amyloid disease affecting primarily synovium and bone in long-term dialysis patients. Rheumatol Int $10: 1-8,1990$

6) Bruckner FE, Burke M, Pereira RS, Eisinger RS, Bending M, Kwan J, Osman AK, Watson B: Synovial amyloid in chronic haemodialysis contains $\beta_{2}$ microglobulin. Ann Rheum Dis $46: 634$ $-637,1987$

7）中澤了一, 五味秀穂, 渡辺幹夫：長期透析における アミロイド骨関節症について，第 5 回腎と骨代謝研 究会記録，協和企画通信，東京，1987，73-79

8) Nakazawa R, Hamaguchi K, Hosaka E, Shishido $\mathrm{H}$, Yokoyama $\mathrm{T}$ : Synovial amyloidosis of $\beta_{2}-$ microglobulin type in patients undergoing long term hemodialysis. Nephron $44: 379-380,1986$

9）平野 宏, 渡辺佳樹, 玉井 仁, 川井伸一郎, 石松 隆子, 佐藤哲也, 佐々木環, 山田昌彦, 栄本忠俊, 松谷拓郎, 進藤 享, 大沢源吾 : 血液透析患者の骨
関節障害一臨床症状のアンケート調査。腎と骨代謝 $4:$ 109-116, 1991

10) Taccari E, Teodori $\mathrm{S}:$ Rheumatoid chyliform bursitis: Pathogenetic role of rheumatoid nodules. Arthritis Rheumatol $27: 221-225,1984$

11) Smith DL, McAfee JH, Lucas LM, Kusum L, Romney DM : Treatment of nonseptic olecranon bursitis. A controlled, blinded prospective trial. Ann Intern Med 149 : 2527-2530, 1989

12) Vartian CV, Septimus EJ : Septic bursitis caused by gram-negative bacilli. J Infect Dis $4: 693-694$, 1985

13) Holder SF, Hopson CN, Vonkuster LC : Tuberculous arthritis of the elbow presenting as chronic bursitis of the olecranon. J Bone and Joint Surg $67: 1127-1129,1985$

14) Reese $\mathrm{W}$, Hopkovitz A, Lifschitz MD : $\beta_{2}$-microglobulin and associated amyloidosis presenting as bilateral popliteal tumors. Am J Kidney Dis $12: 323-325,1988$

15) Fernandez E, Baro P, Montoliu J, Campistol JM, Sole M : Dialysis-associated amyloidosis presenting as a tumour in the elbow. Nephrol Dial Transplant $5: 237,1990$

16) Brancaccio $D$, Gallieni $M$, Padovese $P$, Anelli $A$, Coggi $G$, Uslenghi $C$ : Dialysis amyloidosis with massive popliteal deposition of $\beta_{2}$-microglobulin amyloid. Lancet October 1: 802, 1988 